\title{
O LAZER NO RIO DE JANEIRO, VISTO PELO FOTÓgRAFO AMADOR ALBERTO DE SAMPAIO ${ }^{*} *$
}

$(1900-1910)^{2} * *$

\begin{abstract}
Adriana Maria Martins Pereira
Doutoranda em História Social na Universidade de São Paulo
\end{abstract}

Através da idéia da ação pedagógica da viagem ilustrada, no curso do século XIX, parte de nossa natureza "intocada" fora tratada como atributo da paisagem. A visão romântica carregada de sentidos e categorias de apreensão do espaço impregnou essa forma de olhar, seja mediada pelo modelo da investigação científica ou pela simples fruição de artistas diletantes das mais diversas origens que por aqui estiveram. ${ }^{3}$ Como um vetor de influências, a atividade fotográfica se desenvolveu em meio a essas circunstâncias, sobre as quais aprendemos a observar a paisagem brasileira, adicionando a isso outros agentes, interesses e códigos perceptivos ${ }^{4}$.

Dentro do próprio campo fotográfico, na configuração dos quadros compostos por profissionais e amadores, em que ocorreram inúmeras convergências surgiram, do mesmo modo, diferentes inter-relações. Partimos da hipótese, portanto, de que o fotógrafo amador desse período, embora mantivesse como padrão a atividade do profissional, registra aspectos ainda não "visíveis" na sociedade. Não se trata aqui de demarcar a simples oposição entre aqueles que comercializavam seu trabalho e os que estavam livres das condicionantes do mercado transformando esse dado num valor determinante. É preciso pensar, antes de mais nada, num campo de problemas que nos permita compreender de que forma tais diferenças de percepção foram estabelecidas. Destacamos, para isso, três aspectos principais: o primeiro é a não

\footnotetext{
1* Este trabalho é uma versão ampliada do texto apresentado no Simpósio Temático: História, Imagem e Cultura Visual do XXIV Simpósio Nacional de História da ANPUH, em julho de 2007, na cidade de São Leopoldo, UNISINOS.

${ }^{2}$ ** Agradeço a Elísio de Oliveira Belchior e a Eduardo Soares de Sampaio Filho pela concessão das imagens que analisamos nesse trabalho.

${ }^{3}$ Sob essa perspectiva, a análise se detém no processo de construção da paisagem, identificando as interações com a sociedade que produz e reproduz representações através de imagens tornando-as, nesse processo, em padrão referencial (BELLUZZO, 1999; MENESES, 2002).

${ }^{4} \mathrm{Na}$ apropriação de elementos da pintura, a fotografia também passa a instituir seus próprios códigos (MAUAD, 2000; CARVALHO, 1998).
} 
comercialização de suas imagens, condição básica que diferencia amadores de profissionais; em segundo lugar, as discussões que reiteravam as funções da atividade fotográfica, exercida sob a influência artística e por último, as simplificações dos processos de ordem técnica, aplicadas no campo dos amadores.

A série que iremos analisar, composta principalmente por alguns cartões-postais cujas imagens tiveram ampla circulação no período e os registros instantâneos do amador Alberto de Sampaio, todos tiradas no bairro de Copacabana, pode ser considerada como um modelo dessas mudanças. Nos primeiros anos do século XX, até cerca de 1903, circularam cartões com cenas que privilegiavam a "paisagem natural" em detrimento das atividades humanas e do ambiente construído. A partir de 1907, os atributos da urbanização se transcrevem para a paisagem, transformando os cartões em vetores para a expansão imobiliária do bairro. Nesse mesmo momento o amador, que dialoga com ambas as vertentes, se direciona para o detalhe em contexto. Como uma atividade de formação do olhar, a fotografia amadora permite o encontro com a outra cultura, o trabalho dos pescadores, antecipando assim o retrato dessas populações que ainda não constituíam o foco das lentes da maior parte dos profissionais.

Para o desenvolvimento dos procedimentos de análise escolhemos três conjuntos tomados da mesma região, em torno da pedra da antiga Igrejinha de Nossa Senhora de Copacabana. Os registros seguem ordem cronológica. As datas puderam ser estabelecidas a partir da circulação da imagem, utilizando-se o carimbo do cartão, a assinatura da correspondência ou mesmo comparando-se com a fotografia original. Em alguns casos identificáveis encontramos o autor dos registros, o fotógrafo Marc Ferrez.

\section{Copacabana: entre imagens}

Maria Graham em seu Diário de uma viagem ao Brasil e de uma estada nesse país durante parte dos anos 1821-1823 relata, entre outros acontecimentos, sua visita a Copacabana. A observadora estrangeira defronte à cena faz referências às belas vistas e às matas belíssimas da região, conferindo 
juízo de valor à paisagem. O olhar já educado desses viajantes reconhecia na natureza determinados atributos considerados como parte inerente de sua constituição:

Depois que voltei, juntei-me a um alegre grupo num passeio a cavalo à Copacabana, pequena fortaleza que defende uma das baías atrás da Praia Vermelha e de onde se pode ver algumas das mais belas vistas daqui. As matas das vizinhanças são belíssimas e produzem grande quantidade de excelente fruta chamada cambucá [...] (1956: 301, grifo nosso).

Esse modelo de viajante estabeleceu, ao longo do século XIX, modos de ver que passamos a considerar, mais tarde, como características naturais da paisagem brasileira. A partir do confronto de culturas díspares, se estabeleceram formas de apreciação cujas influências ultrapassaram o simples registro documental (BELUZZO, 1999). No cartão-postal de autoria do fotógrafo Marc Ferrez é possível identificar alguns desses elementos (FIGURA 1). A imagem de formato panorâmico, tirada na praia do Diabo, entre Copacabana e Ipanema traz, num primeiro plano, um homem em destaque, defronte o mar. O cenário não se expande ao infinito; ao contrário, com a presença da pedra do Arpoador ao fundo tudo está circunscrito dentro de um espaço limitado.

No registro, o fotógrafo dialoga com alguns aspectos da noção de "sublime", um conceito de representação da natureza que, além da categoria do "belo", se tornou num padrão difundido por meio da iconografia e de relatos produzidos pelos viajantes europeus que por aqui estiveram (Id., Ibid.). A combinação da imagem panorâmica, condensando o valor de substituto da própria realidade representada, ao lado do personagem local, retratado a partir de um ponto de vista elevado, confere escala à cena e, acima de tudo, leva ao extremo a relação da imensidão da natureza com a pequenez do homem. O olhar selecionava, deste modo, elementos que transmitiriam sensações e subjetividades, construindo o sublime na paisagem.

Para manter a panorâmica, Marc Ferrez utilizou dois cartões juntos, recurso, aliás, comum em situações em que se objetivava ampliar o espaço da imagem e, no outro caso, foi deixada uma margem em branco na parte superior do papel - na correspondência, encontramos a data de envio, 1903, e o nome do remetente, Paulo Godoy, no carimbo (FIGURA 2). É preciso considerar que Ferrez 
era herdeiro direto desse modelo de observação, tendo sido um dos mais importantes e influentes profissionais do período. Descendia de uma família que, além de integrar a Missão Artística Francesa participou dos círculos da Academia Imperial de Belas Artes (TURAZZI, 2002). Nesse caso, a fotografia pode ser entendida como o pólo de um processo muito mais amplo de construção da paisagem "natural" brasileira, que começava a alcançar outra difusão, através dos cartões-postais.

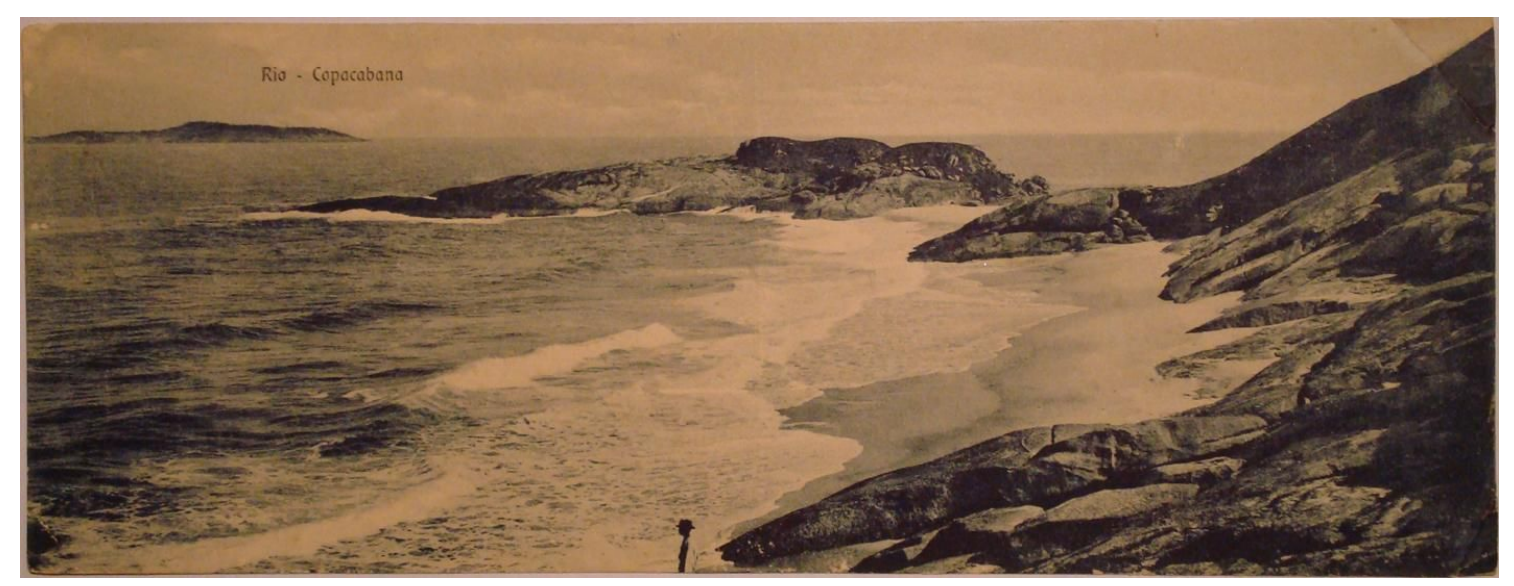

FIGURA 1. "Rio - Copacabana". Cartão-postal. Praia do Diabo. Autor: Marc Ferrez.

Coleção Elísio de Oliveira Belchior.

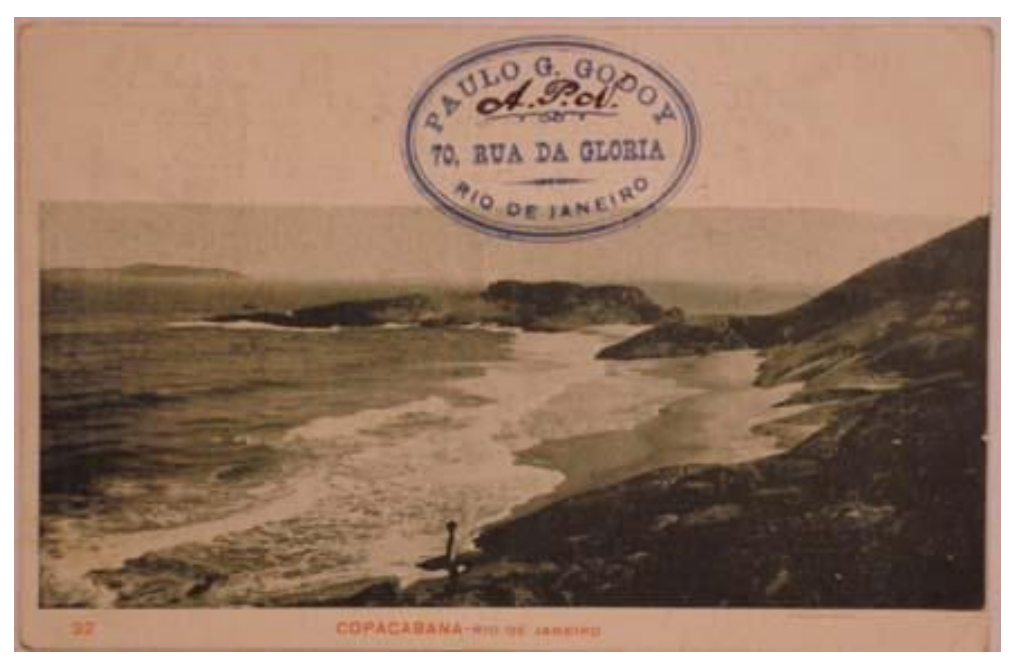

FIGURA 2. "Copacabana - Rio de Janeiro". Cartão-postal. Praia do Diabo. Data da correspondência: 1903.

Autor: Marc Ferrez.

Coleção Elísio de Oliveira Belchior. 
Do mesmo ponto sob o qual era possível observar a pequena praia do Diabo ficava a Igrejinha, um dos principais marcos de toda essa região. Sua origem remonta a uma capela construída no século XVIII para abrigar a imagem da santa Nossa Senhora de Copacabana, que mais tarde deu origem ao nome do bairro. Foi muitas vezes reformada, tendo sido descrita pelo inglês John Luccock (1951: 189), em Notas sobre o Rio de Janeiro tomadas durante estada de dez anos nesse país, de 1808-1818, como uma "capelinha redonda, quase em ruínas". Mas nos relatos de Jean Baptiste Debret, em sua Viagem pitoresca e histórica ao Brasil, 1816-1831, encontramos uma descrição mais completa:

\footnotetext{
"Vê-se no meio da areia a pequena igreja de Copacabana isolada num pequeno platô, mais a direita um segundo plano, formado por um grupo de montanhas, entrando pelo mar e esconde a sinuosidade do banco de areia, cuja extremidade reaparece com sua parte cultivada [...]"(1940: 286).
}

A presença de Debret na região antecede, em muito, ao ano de 1858, momento em que a antiga capela foi substituída pela Igrejinha difundida por meio da iconografia, a partir da segunda metade do século XIX ${ }^{5}$. No entanto, encontramos, nessa narração, alguns elementos que estiveram presentes em muitas das tomadas posteriores da ermida, como os dois cartões-postais idênticos cuja autoria não foi possível identificar - ambos estiveram em circulação em 1903 (FIGURA 3 e 4). O colorizado fora impresso na Alemanha, segundo a indicação textual, tendo sido publicado pela papelaria Ribeiro, do editor de postais Alexandre Ribeiro, um dos mais importantes do Rio de Janeiro da época (VASQUEZ, 2002).

\footnotetext{
5 A Igrejinha foi demolida em 1918, na etapa final da construção do Forte de Copacabana (BERGER: 1959).
} 


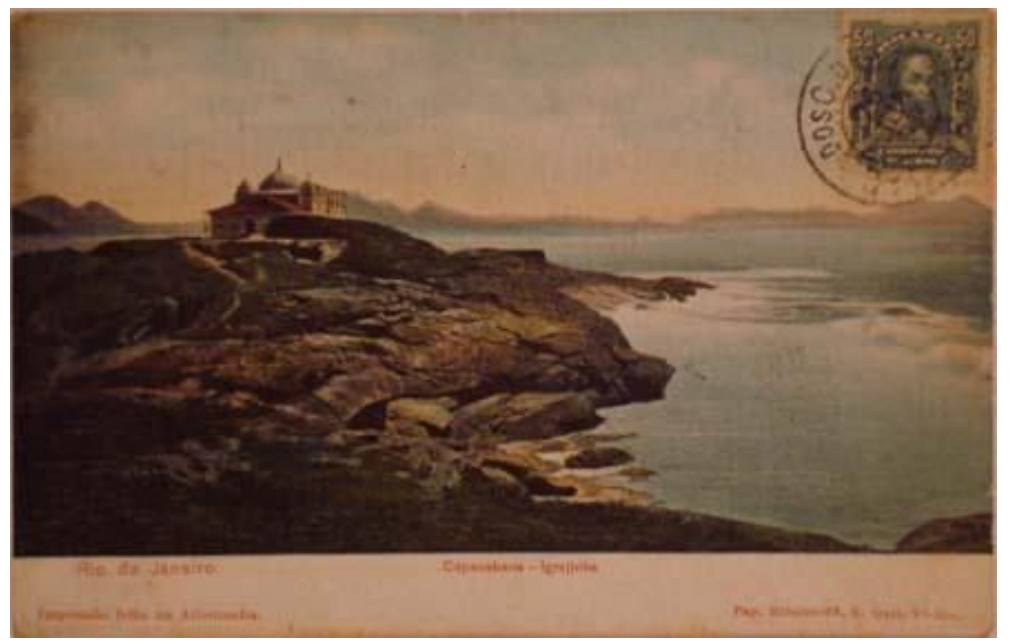

FIGURA 3. "Rio de Janeiro. Copacabana - Igrejinha. Impressão feita na Alemanha. Pap. Ribeiro-95, R. Quit. 97-Rio". Cartão-postal. Igrejinha de Nossa Senhora de Copacabana.

Data da correspondência: 1903.

Autor desconhecido.

Coleção Elísio de Oliveira Belchior.

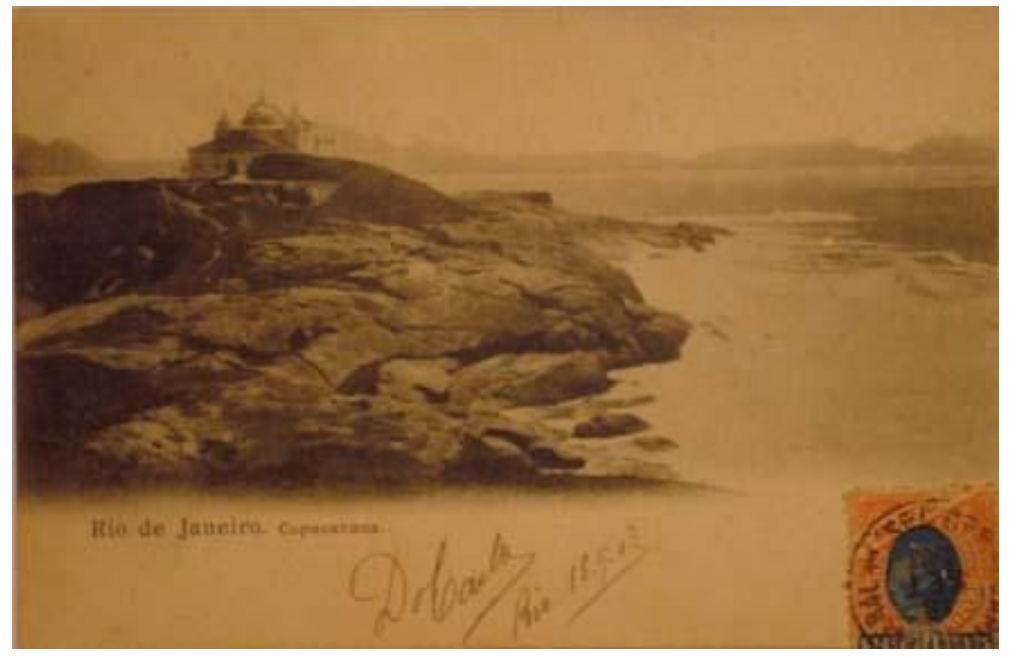

FIGURA 4. "Rio de Janeiro. Copacabana". Cartão-postal. Igrejinha de Nossa Senhora de Copacabana.

Data da correspondência: 1903.

Autor desconhecido

Coleção Elísio de Oliveira Belchior. 
Há convergências consideráveis entre as imagens e o relato de Debret, segundo os quais a igreja e o conjunto de montanhas quase se fundem, "entrando pelo mar", isso porque o edifício, situado na parte esquerda, se agrupa visualmente ao último plano formado pela cadeia de montanhas. Nota-se que uma grande parte do quadro é composta pela "natureza intocada", sem haver qualquer referência a limites como muros ou outro elemento que indicasse ordenação pelo trabalho humano. O fotógrafo deu ênfase, dessa maneira, à formação geológica do morro, em pedra, cujo lugar mais alto é ocupado pela igreja. Segundo essa configuração, os dois elementos constituídos como marcos da paisagem natural e construída são igualados e a arquitetura se transforma num componente da própria paisagem.

A Igrejinha de Nossa Senhora de Copacabana serviu também de base a uma tomada, cujo ponto de vista foi extremamente difundido na primeira década do século XX (FIGURA 5). Ao se posicionar em direção à praia de Ipanema outros fotógrafos, além de Marc Ferrez, escolheriam esse mesmo trecho, repetidas vezes. Certamente, essa preferência se deve, em parte, por ser a única área em que havia maior número de construções no bairro. Segundo Gilberto Ferrez (1985) a fotografia original data de 1895, no entanto, constatamos que sua circulação em cartão-postal ocorreu somente na primeira década do século XX a correspondência é de 1903.

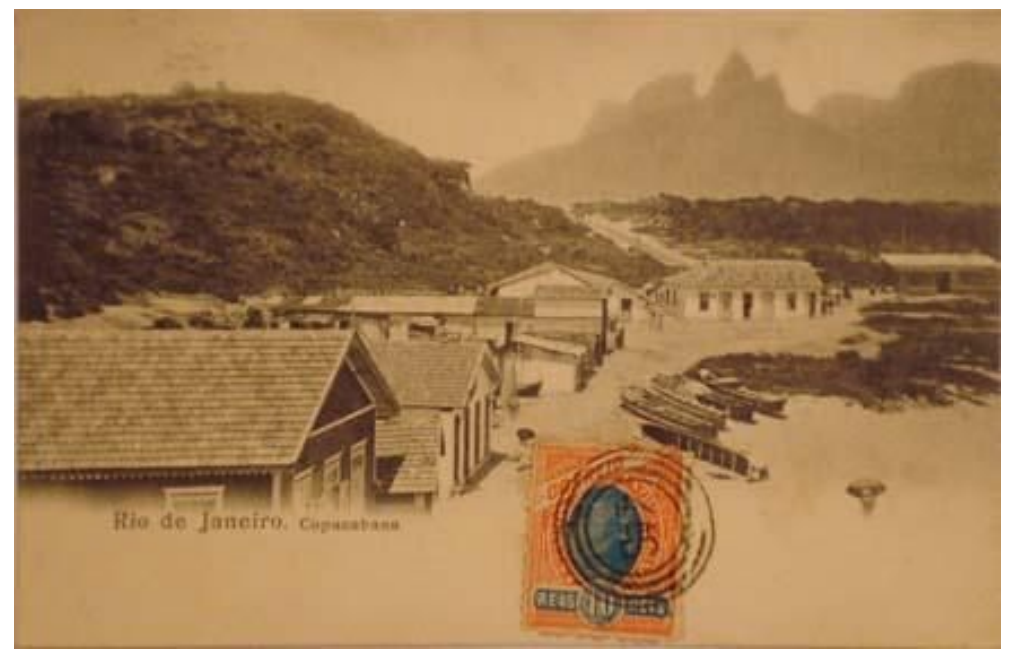

FIGURA 5. "Rio de Janeiro. Copacabana". Cartão-postal. Foto original de acordo com Gilberto Ferrez, 1895.

Data da correspondência: 1903.

Autor: Marc Ferrez - Coleção Elísio de Oliveira Belchior. 
Nas proximidades desse conjunto edificado em 1873 estabeleceu-se a primeira ligação telegráfica que permitia a comunicação com o norte do Brasil, empreendimento realizado pelo Barão de Mauá. Havia uma pequena construção que abrigava a entrada do cabo da Brazilian Submarine Telegraph Company, cuja ligação final foi realizada na presença do próprio Imperador D. Pedro $\mathrm{II}^{6}$. Para gerenciar as atividades e fazer manutenção constante dos aparelhos funcionários da companhia passaram a morar numa residência, que possivelmente está incluída da foto, a denominada pela população carioca da época como a "casa dos ingleses" (GERSON, 2000).

Isso nos traz algumas pistas embora não possamos identificar, de maneira precisa, qual casa pertencia à companhia. De qualquer forma, observamos que a apropriação do território não fora ordenada, ao contrário, tudo indica que o crescimento aconteceu de forma espontânea. Sem a delimitação entre o terreno privado e o público, o limite de cada residência era a própria habitação, e mesmo o espaço que seria formado pela rua tem traçado irregular se confundindo com a areia, local em que se encontram as canoas dos pescadores. Nota-se que todo o conjunto está disposto em forma de arco acompanhando a geografia do ambiente. O único indício da existência de um traçado geométrico é a rua que dá acesso ao lado oposto, em direção à Villa de Ipanema, hoje bairro com o mesmo nome. Ao atravessarmos a área de vegetação densa, cortada por esse primeiro logradouro, nosso olhar é conduzido para o último plano constituído pela cadeia de montanhas do morro Dois Irmãos e da pedra da Gávea. Trata-se da antiga rua da Igrejinha, atualmente Francisco Otaviano ${ }^{7}$.

O padrão diferenciado de ocupação indica uso misto do território. Não é o caso, portanto, de serem apenas casas pertencentes à colônia dos pescadores, como é possível perceber no primeiro plano em que, inclusive, há dois mastros num deles a bandeira está hasteada na fachada de uma das residências (DETALHE 1). Ao lado do conjunto cujas condições de estrutura são mais precárias, observa-se parte de uma embarcação, o que indica ser ali local de moradia, de trabalho ou guarda de material dos pescadores, figura essa representada pelo homem que observa o fotógrafo, no primeiro plano, com chapéu. A valorização do ambiente construído em relação à massa composta pela

\footnotetext{
6 A comunicação com a Europa aconteceu somente no ano de 1874, quando a empresa já se chamava Western Telegraph Company (DUNLOP, 1973).

${ }^{7}$ A rua da Igrejinha foi aberta entre 1892-94 pela Empreza de Construções Civis (GERSON, 2000). 
vegetação e montanhas ocorre em detrimento da exclusão do espaço da praia, que não aparece na imagem. O isolamento do pequeno conjunto edificado, em relação à cidade do Rio de Janeiro se configura, desse modo, na associação entre o espaço geográfico e os elementos agrupados, paisagem que concretiza o olhar sobre o pitoresco.

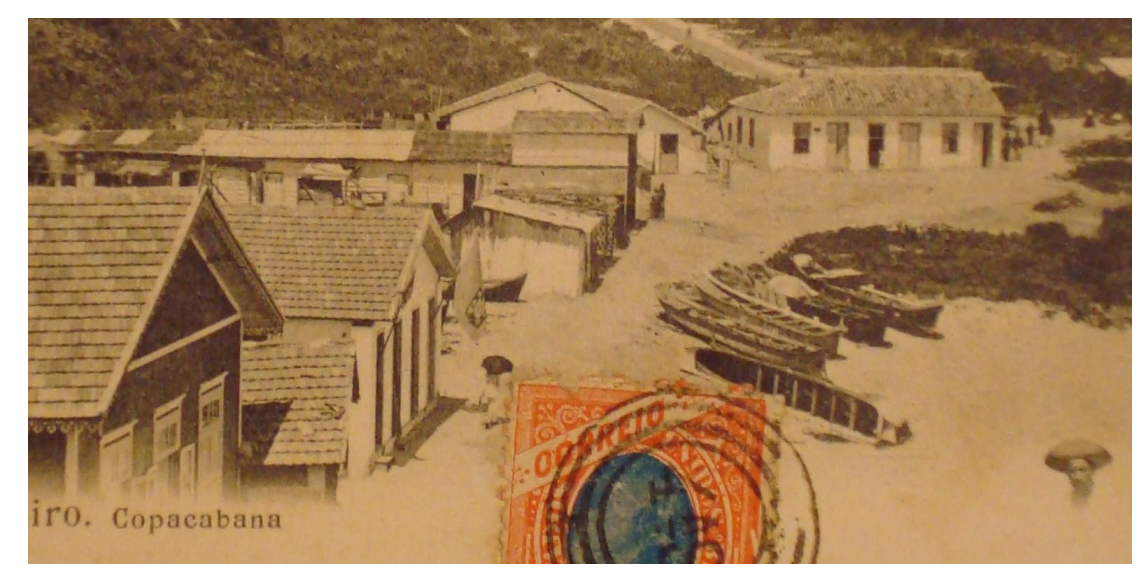

DETALHE 1. Observa-se dois mastros na fachada da terceira casa à esquerda, num deles a bandeira está hasteada.

Como esse ponto de vista fora retomado inúmeras vezes por diversos profissionais, ao longo da primeira década do século $X X$, identificamos outros elementos sendo adicionados a esse cenário. O próprio Marc Ferrez atualiza sua imagem que passa a circular, por meio de cartões-postais, em 1907 (FIGURA 6). Apesar do ponto de vista escolhido ser idêntico, a posição da tomada torna-se descendente permitindo, assim, que a cena se estenda englobando um maior trecho da própria paisagem. A partir da pequena mudança de eixo, aparece o indício da existência do mar em dois trechos: no primeiro plano e, ao fundo, na parte intermediária à frente da cadeia de montanhas - no caso a praia de Ipanema. No lugar da rua onde antes havia apenas canoas existe, agora, sinal de desenvolvimento como os postes de iluminação e a indicação da linha de bondes, que já chegava até a Igrejinha. 


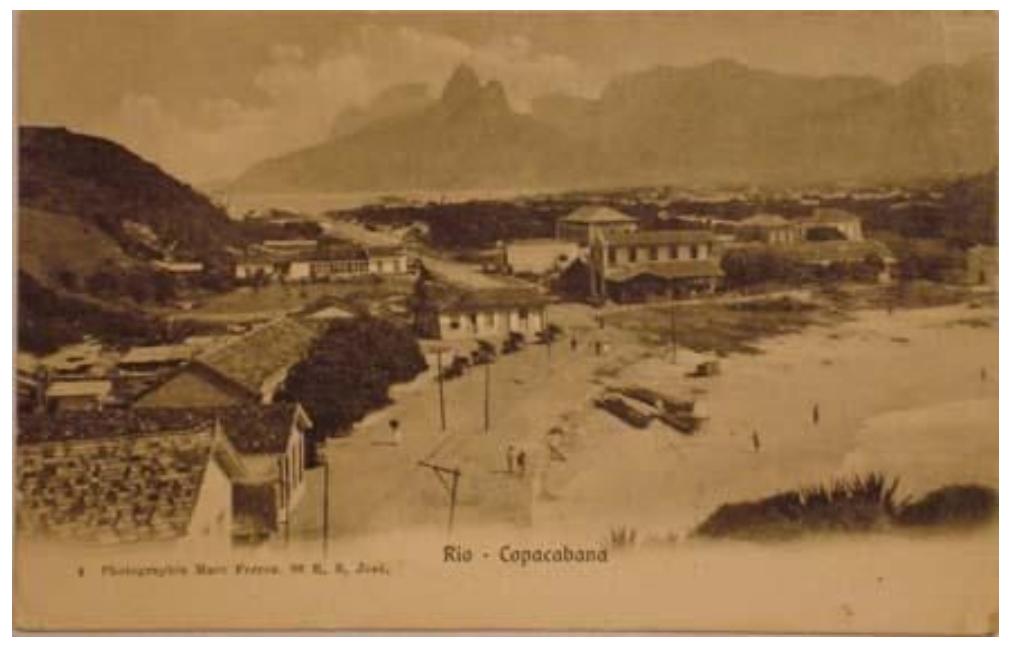

FIGURA 6."Photographie Marc Ferrez, 96, R. S. José, Rio - Copacabana". Cartão-postal.

Data da correspondência: 1907.

Autor: Marc Ferrez - Coleção Elísio de Oliveira Belchior.

O modelo das novas residências segue outra tipologia apresentando, em sua maioria, dois pavimentos e varanda. Embora seja possível identificar crescimento de forma um pouco mais ordenada, ainda não ocorria substituição do espaço construído. Vale lembrar que, nesse momento, o número de habitações aumentara significativamente, considerando-se o padrão anterior de desenvolvimento do bairro ${ }^{8}$. Segundo Ferreira da Rosa, em 1905, Copacabana já contava com cerca de 600 casas (CARDOSO, 1986). Rápidas mudanças eram uma realidade para um local que permaneceu durante muito tempo praticamente isolado, não estando incluído na área de expansão da cidade. A dificuldade de acesso, associada à cultura que excluía o espaço da praia da vida social, contribuíram para essa configuração.

Somente com as mudanças na passagem do século XIX, na organização da sociedade do Rio de Janeiro, é que começaram a surgir investimentos maciços em infra-estrutura. A venda e loteamento de terrenos, implementação de transporte público, abertura de túneis e abastecimento de água foram algumas das benfeitorias ocorridas em Copacabana. As diversas ações foram realizadas numa associação entre a Companhia de Ferro Carril Jardim Botânico, a Empreza

\footnotetext{
${ }^{8} \mathrm{~A}$ casa de dois pavimentos que ficava na esquina da rua da Igrejinha com a praia, segundo Brasil Gerson (2000), era o local em que a Companhia Ferro Carril Jardim Botânico fez a primeira estação de bondes da área, inaugurada em 1894. O jornalista Edmundo Bittencourt comprou o imóvel e alugou para Mme. Chabas, francesa que ali instalou um misto de restaurante e cabaret conhecido como Mère Louise.
} 
de Construções Civis e a prefeitura da cidade. Enquanto a empresa de bondes alocava recursos para obras como, por exemplo, instalação de trilhos e perfuração de túneis, recebendo em troca concessões da prefeitura para explorar as linhas, a imobiliária se responsabilizava diretamente pela urbanização e abertura de novas vias públicas em meio ao imenso areal (SANTOS, 1996).

No entanto, mesmo dentro do próprio grupo da Companhia havia muitas resistências em relação aos investimentos propostos para área. Consta, num relatório de 1894, a resposta de seus diretores repudiando a crítica recebida por um grupo de acionistas que identificaram Copacabana como um "deserto de Saara". A resposta da diretoria é afirmativa. Esse bairro "a criar-se" iria se transformar num lugar para onde se direcionaria a população da cidade, quando os banhos de mar se incorporassem às práticas cotidianas da população carioca, modelo condizente com o que acontecia nas cidades litorâneas da Europa (Id., Ibid).

Incrementando esse quadro, na última década do século XIX, a cidade do Rio de Janeiro sofreu com grandes epidemias de febre amarela. No período entre os anos 1891-1894 os óbitos ultrapassaram cerca de 4 mil casos, exatamente no mesmo momento em que começaram as primeiras ações concretas para urbanização de Copacabana (VILLAÇA,1998). É verdade que a idéia do bairro ser um refúgio benéfico para saúde já tinha seus adeptos em meados dos oitocentos, mas o acesso era muito difícil e esse hábito não se popularizou. Somente com a abertura, pela Companhia Jardim Botânico, do túnel da Real Grandeza em 1892,

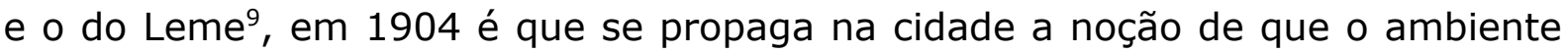
da praia favorecia ao bem estar e podia ser utilizado para fins terapêuticos. Tal cenário está demarcado no relatório de 1894, da mesma Companhia. Nesse texto, os diretores afirmam que Copacabana e Arpoador são dois "verdadeiros sanatórios por onde pode respirar largo a população desta capital na estação calmosa, em que é infelizmente dizimada por epidemias periódicas e mortíferas" (apud SANTOS, 1996: 247). ${ }^{10}$

Todos esses fatores compõem alguns eixos sobre os quais essas imagens foram produzidas e comercializadas. No próximo cartão, também tomado da Igrejinha em direção a Ipanema, uma pequena mudança no ponto de vista altera

\footnotetext{
${ }^{9}$ Atualmente são conhecidos como túnel Alaor Prata (túnel Velho) e túnel Novo.

10 No relatório de 1894 da Companhia Ferro Carril Jardim Botânico consta que o governo já havia instalado em Copacabana dois hospitais beribéricos (DUNLOP, 1953).
} 
a interpretação da cena - a correspondência é 1907 (FIGURA 7). O ângulo de observação, agora, privilegia diretamente o traçado em perspectiva central da única rua que havia sido planejada, a rua da Igrejinha, criando a ilusão de que as construções no entorno estão em maior número. A valorização dessa linha geométrica se tornará num modelo para diversos postais que passam a circular nesse momento (FIGURA 8). Os pescadores, entretanto, foram retratados seguindo o mesmo padrão já identificado: temos os personagens na pedra observando o mar e o artefato, os barcos, dispostos na areia.

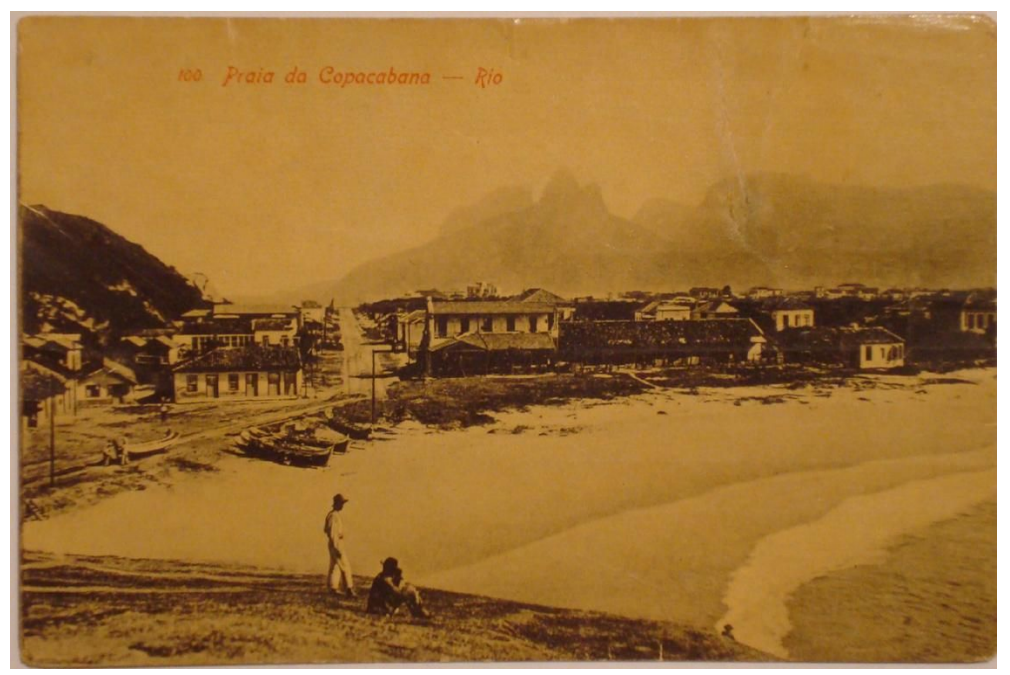

FIGURA 7. "Praia de Copacabana - Rio". Cartão-postal. Data da correspondência: 1907

Autor desconhecido. Coleção Elísio de Oliveira Belchior.

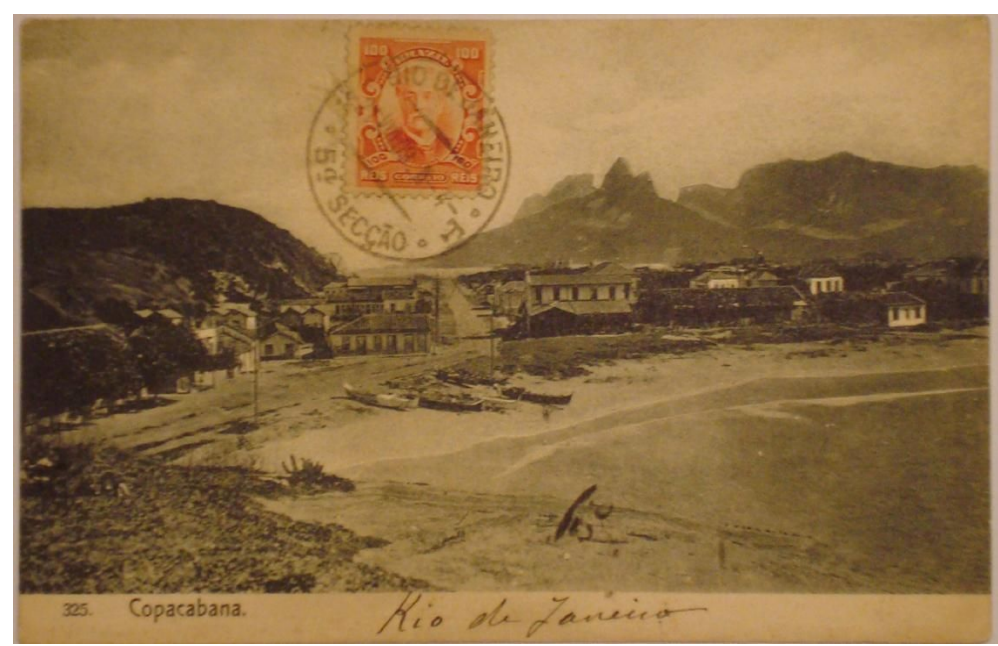

FIGURA 8. "Copacabana". Cartão-postal.

Autor desconhecido. - Coleção Elísio de Oliveira Belchior. 
É claro que a Copacabana vista pelo olhar pitoresco não desaparece por completo nessas imagens, porém ganha outros contornos em face dos conflitos existentes a partir daquilo que se veiculava como possibilidade futura e a realidade da situação em curso. A idéia de modernização, experimentada por determinados setores da sociedade, está também implícita na legenda do cartão que traz o título em destaque: "Melhoramentos de Copacabana" (FIGURA 9). Para validar a leitura que a legenda busca conferir à imagem, o recurso utilizado, mais uma vez, é a rua tomada em perspectiva central, situada entre as duas manchas azuis que demarcam o espaço da praia.

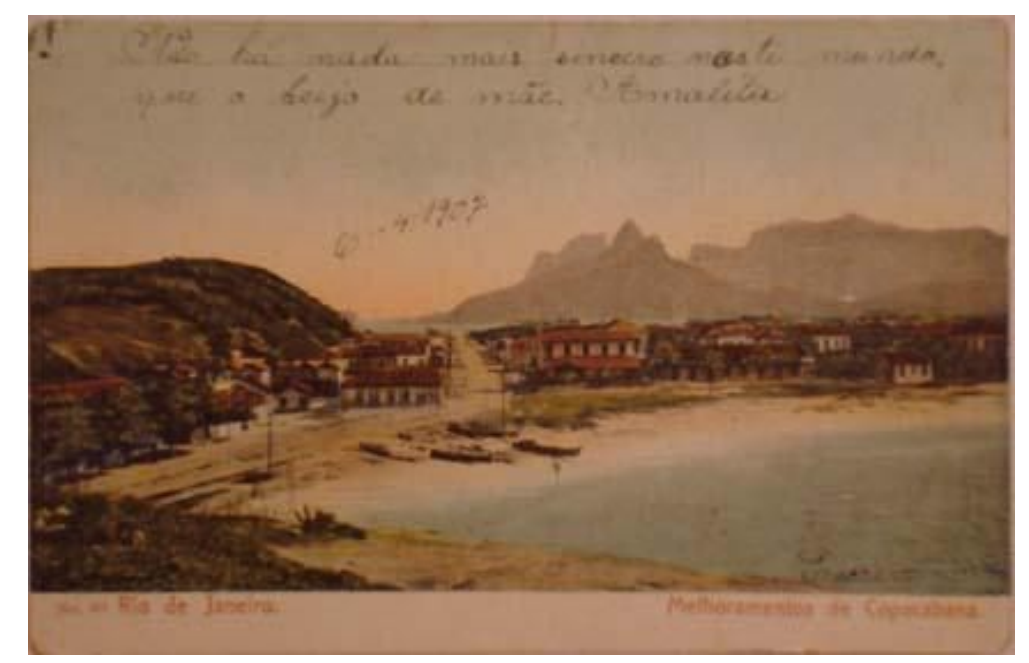

FIGURA 9. "Rio de Janeiro. Melhoramentos em Copacabana". Cartão-postal. Trata-se da mesma imagem da Figura 8.

Data da correspondência: 1907.

Autor desconhecido. - Coleção Elísio de Oliveira Belchior.

A uma primeira vista, o que se compreende por "melhoramento" se dilui num lugar tão pouco habitado. De fato, sabemos que tudo era ainda muito precário. Os logradouros públicos não tinham nem mesmo meio-fio ${ }^{11} \mathrm{e}$, devido à falta de pavimentação, nos dias de chuva, muitos lugares recém-abertos ficavam praticamente intransitáveis ${ }^{12}$. Em meio a esse cenário de desenvolvimento incipiente, as empresas envolvidas no crescimento imobiliário do bairro não pouparão esforços para atrair novos moradores e visitantes. Em 1905, a Companhia Ferro Carril Jardim Botânico criou um bar campestre no Leme e

\footnotetext{
${ }^{11}$ Segundo Brasil Gerson (2000) havia um morador, Henrique do Espírito Santo, que os colocava por 8 mil réis o metro-linear, até os anos 1910 .

${ }_{12}$ Somente em 1911 que as principais vias começam a ser pavimentadas pela prefeitura, com macadame betuminoso (ABREU, 1988).
} 
imprimia também, nos versos dos bilhetes dos bondes, pequenas estrofes para atrair a clientela, apelidadas pelos cariocas como "conselhos de higiene poética" (apud BERGER, 1959: 57).

Graciosas senhoritas, moços chiques,

Fugi das ruas, da poeira insana:

Não há lugares para piqueniques

Como em Copacabana.

Pedem vossos pulmões ar salitrado

Correi, antes que a tísica os algeme,

Deixai o Rio o centro infeccionado,

Tomai um bonde que vai dar no Leme...

Ó pais que tendes filhos enfezados

Frágeis e macilentos e nervosos,

Afastai-os da manga e da banana.

Á beira-mar! Aos ares salitrados!

E hei de vê-los rosados e viçosos...

Para Copacabana!

E nos jornais a Companhia publicava: "Passeio agradável e refrigerante.

Copacabana. Bonde até às 2 horas da manhã" (apud CRULS, 1949: 539).

Nesse mesmo momento, a reforma Pereira Passos (1902-1904) havia transformado uma parte da fisionomia urbana da cidade do Rio de Janeiro de forma radical. O debate, veiculado na imprensa, incorporou ao cotidiano dessa população todo um discurso que associava as transformações ocorridas à idéia de "modernização". A inclusão do espaço da praia, seja para lazer ou para fins de saúde, era a tônica dos discursos. No jornal Gazeta de Notícias, de 1904, encontramos um trecho bem esclarecedor:

Todos os leitores conhecem bem aquelle pedaço de céo que se chama Copacabana, que se está tornando uma encantadora cidade. Com os melhoramentos já projetados pela prefeitura e pela Companhia Jardim Botânico... à Copacabana ficará reservado futuro grandioso, tanto mais quanto será essa a única praia de banho de que nos podemos servir, porque as actuaes desapparecerão com os melhoramentos que estão fazendo na cidade... (apud PEREIRA, 1992: 191). 
Alguns aspectos das ações em voga, no período, podem ser observados na tomada em formato de estereoscopia ${ }^{13}$, da rua da Igrejinha (FIGURA 10). Apesar de ter sido retratada sob o ponto de vista lateral, de forma semelhante aos cartões de Ferrez, nota-se a presença de uma parte do poste de iluminação. Como um símbolo dos melhoramentos, o poste e os fios atravessam o espaço fotográfico condensando signos presentes no período. Esta configuração, longe de representar um acaso, confirma a existência de um elemento comum que passou a nortear a apreciação da paisagem. O modelo do ambiente com conteúdo em parte "modernizado", mediado pela experiência da terceira dimensão, convidava o espectador a participar e, ao mesmo tempo, estar incluído na cena. O poste, sob essa perspectiva, ganha dimensão física, uma materialidade que não é fortuita.

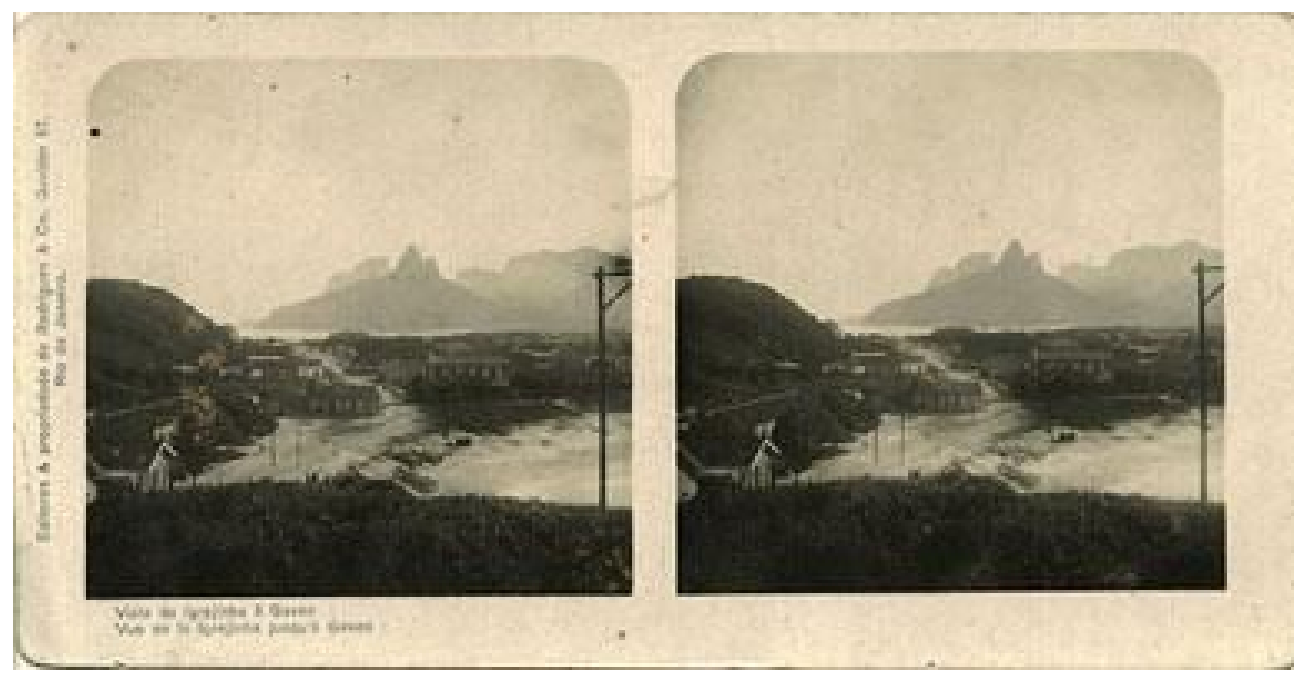

FIGURA 10. "Vista da Igrejinha à Gávea. Editores \& propriedade do Rodrigues e Co. Ouvidor 57". Cartão fotográfico. Esta imagem pertencia a Alberto de Sampaio.

Autor desconhecido. - Coleção Eduardo Soares de Sampaio Filho.

$\mathrm{Na}$ primeira década do século XX, a Empreza de Construções Civis, companhia envolvida na urbanização do bairro produziu, ela mesma, vinte cartões-postais de Copacabana. A função principal dessas fotografias era atuar como propaganda. O meio extremamente eficaz de comunicação passava, desse

\footnotetext{
13 Para a realização de fotografias em formato estereoscópico era necessário utilizar câmera especial com objetivas idênticas, separadas a uma distância de $6,3 \mathrm{~cm}$, semelhante à dimensão média entre o centro ótico dos olhos humanos. Ao observar o par de fotografias, com um visor apropriado, tinha-se a ilusão tridimensional. Esse tipo de suporte que podia ser adquirido da mesma forma que os postais, com preço reduzido, se transformou também em objeto de colecionismo (PARENTE, 1999).
} 
modo, a difundir valores dentro do contexto de produção e consumo da sociedade capitalista. É preciso lembrar que no período da denominada "febre" dos postais, segundo Luis Edmundo (1957:716), eles eram o "delírio" que empolgava o carioca, situação essa que a empresa imobiliária soube tirar proveito.

Em meio à série que entrou em circulação, há uma tomada feita da pedra da Igrejinha, porém o ângulo de visão é um pouco diferente (FIGURA 11). A cadeia das conhecidas montanhas em direção a Ipanema foi substituída pelos morros de Copacabana, já que o destaque era o local cujos terrenos estavam sendo vendidos. Mesmo considerando a mudança do posicionamento do fotógrafo, devido à função pragmática que os postais passam a ter, a organização da imagem não apresenta nenhuma diferença substancial além, é claro, de uma maior inclusão do espaço da praia. No primeiro plano os pescadores, segurando a rede, são novamente dados figurativos da paisagem que apresenta alguns traços de urbanização, como é possível notar no destaque dos postes de iluminação elétrica.

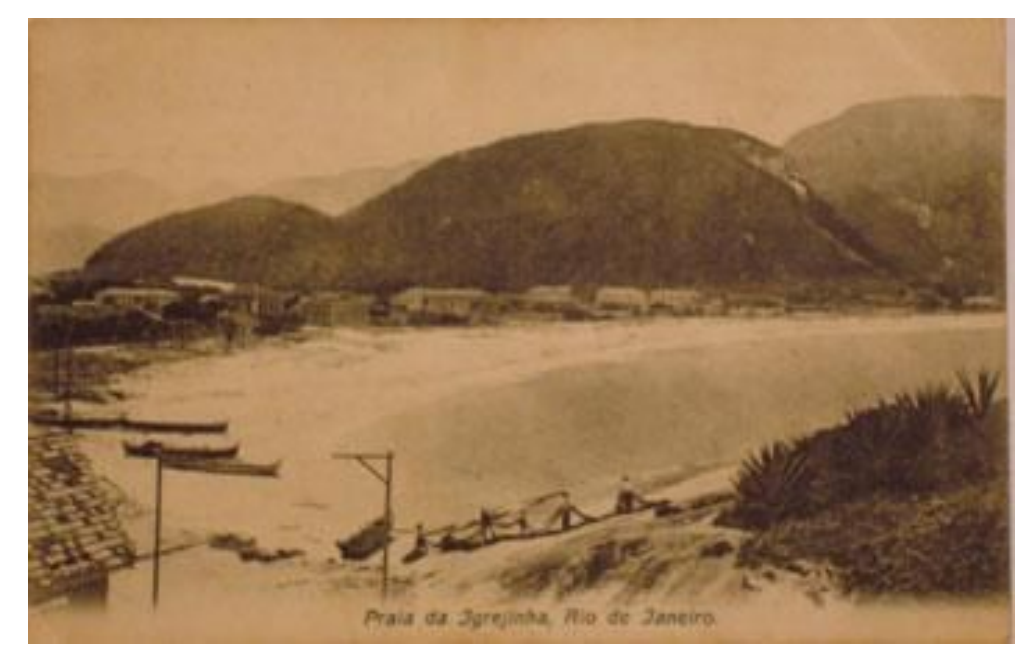

FIGURA 11. "Praia da Igrejinha, Rio de Janeiro". "Empreza de Construções Civis", verso. Cartão-postal. Data da correspondência: 1907.

Autor desconhecido. - Coleção Elísio de Oliveira Belchior

A fotografia, nesse caso, servia de meio de divulgação de uma nova área urbana - nos versos dos cartões havia o nome da empresa. Não seria equivocado supor, contudo, que mesmo os postais produzidos de forma independente dos interesses imobiliários tiveram também, a partir de um determinado momento, 
papel de vetores para a divulgação das melhorias do bairro. As paisagens difundidas por meio dos cartões-postais e estereoscopias tornaram-se, assim, num poderoso aliado aos interesses e disputas sobre o espaço físico dessa Copacabana. A simples mudança de posição dos fotógrafos, ao passarem a retratar a antiga rua da Igrejinha sob perspectiva central, valorizando o único eixo com uma pré-urbanização, reafirma nossa hipótese. Não é por casualidade, portanto, que a Empreza de Construções Civis utiliza maciçamente esse recurso.

\section{Fotografia amadora: Alberto de Sampaio}

Alberto de Sampaio (1870-1931) desenvolveu parte de suas atividades profissionais como advogado no Rio de Janeiro, cidade em que nasceu e em Petrópolis, onde manteve residência fixa a partir da década de 1890. A fotografia amadora, praticada paralelamente ao exercício da advocacia constituía, assim, um segundo eixo que marca sua personalidade. Podemos considerá-lo um amador de acordo com o modelo estabelecido em fins do século XIX, em que homens das classes mais privilegiadas se dedicavam à fotografia, possuindo conhecimentos técnicos e estéticos de forma muito próxima aos profissionais. Para essa formação era imprescindível a leitura de manuais e de revistas especializadas, publicações em que era possível obter informações sobre técnicas, divulgar concursos etc. (PEREIRA, 2002). Esses manuais e periódicos que circulavam no Brasil eram, em sua maioria, de origem francesa, mas havia também, em menor número, exemplares em inglês, italiano e alemão.

$\mathrm{Na}$ geração de Sampaio, duas mudanças consideráveis incrementaram o desenvolvimento do campo amador. A primeira foi a popularização dos negativos de placa seca que substituíram o sistema do colódio úmido, processo trabalhoso que exigia, inclusive, a sensibilização do material no momento de tomada da imagem. A segunda mudança ocorreu com o lançamento da câmera Kodak em 1888. Essa companhia transformou a possibilidade de apenas se apertar um botão para fotografar num slogan potente, que a fez vender milhares de câmeras como os populares modelos Brownie e Detetive. A introdução dessas novas 
tecnologias teve como resultado a gradativa inserção da fotografia no ambiente doméstico deixando de ser, conseqüentemente, exclusividade daqueles que dominavam os procedimentos técnicos e estéticos que o meio ainda exigia (WELLS, 2004).

Segundo a percepção dos amadores que participavam de clubes e sociedades, sobretudo nos países europeus, o uso desses métodos e equipamentos mais simplificados empobrecia a atividade (POIVERT, 2001). No Brasil, entretanto, no momento em que ainda não havia clubes seguindo esse modelo, somado à influência constante de todo tipo de informarão recebida por meio das publicações importadas, é possível notar a mistura entre esses dois eixos. Dessa maneira, caracterizavam-se fotógrafos amadores como Alberto de Sampaio. Podiam ter conhecimentos tal como profissionais possuindo laboratórios adequados para a realização dos processos de revelação e ampliação das chapas e, ao mesmo tempo, não dispensavam o uso de aparelhos cujo manuseio era mais automatizado. Os periódicos e manuais direcionados a esses amadores ou diletantes, como eram chamados nos países de língua espanhola e italiana, divulgavam sobre ambas as possibilidades.

Entre os manuais que por aqui circularam, como o Guide du photographe amateur de A. Granger, publicado em 1895, há informações que englobam técnicas complexas ao lado de capítulos dedicados aos Procede e Appareils Eastman. Outro manual bem popular no período, o Manual do photographo ou guia pratico do amador photographico, foi publicado em 1908, de autoria Alberto Pereira Carvalhal. Da mesma forma, encontramos dados a respeito de laboratórios, diafragmas, processos de revelação e também sobre câmeras, papéis e negativos de fabricação da Kodak. É inegável que a facilidade e leveza desses equipamentos seduziam tanto os fotógrafos cujo conhecimento já havia sido sedimentado, como aqueles que se iniciavam na atividade. Por essas circunstâncias, sendo um pólo de aplicação de tecnologias e herdeiros de um determinado olhar, uma parte desses amadores continua a dialogar com as imagens produzidas pelos profissionais, sua referência principal e, do mesmo modo, experimentam as tecnologias recém lançadas no mercado. 


\subsection{A série dos pescadores}

Na primeira década do século XX, Alberto de Sampaio realizou diversas tomadas dos bairros litorâneos do Rio de Janeiro. Algumas das fotografias seguem a mesma configuração das cenas encontradas em muitos cartões-postais do período. O amador, nesse caso, praticamente repete as cenas já conhecidas, como se estivesse lidando com a combinação de elementos de um mesmo repertório.

A forma e o conteúdo de suas imagens, no entanto, por vezes fogem às regras estabelecidas pelo cânone, características sobre as quais iremos nos debruçar na análise da série dos pescadores. Em torno dos anos 1906, Sampaio fez várias tomadas da região; em uma delas, ele se posiciona no espaço da areia, retratando em primeiro plano as canoas dos pescadores, na mesma direção do cartão-postal comercializado pela Empreza de Construções Civis. Deixa de lado, assim, o local que permitia a vista abrangente do entorno, onde se situava a pedra da Igrejinha (FIGURA 12). Na organização desse quadro, o artefato ganha um novo estatuto, ao deixar de ser um simples componente do conjunto para se tornar em objeto central. Por esse motivo, os elementos constitutivos do ambiente, no último plano composto pelas casas e morros, estão desfocados. Embora o registro tenha alta qualidade, devido ao negativo (placa seca) em suporte de vidro de $8,0 \times 10 \mathrm{~cm}$, não foi utilizado o recurso da profundidade de campo. 


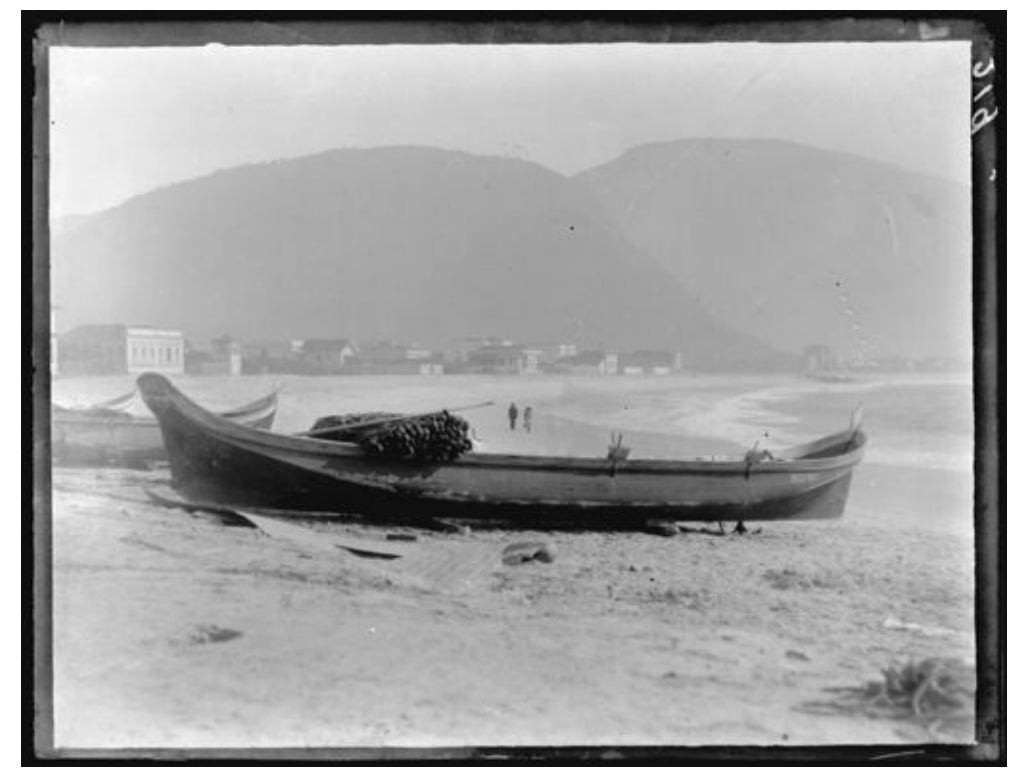

FIGURA 12. "Barco em Copacabana". Contato a partir de negativo de vidro (placa seca), 8,0 x $10 \mathrm{~cm}$. Título do autor.

Data: 1906.

Autor: Alberto de Sampaio. - Acervo Eduardo Soares de Sampaio Filho

Essa mudança do ponto de vista possibilita uma outra experiência com o espaço, agora organizado em função da paisagem e não por ela determinado. Não é possível, certamente, considerar os fatores econômicos como elementos cruciais para essa alteração, ou seja, uma espécie de liberdade que esse amador teria por não comercializar o produto de seu trabalho. Isso porque, ao elaborar a imagem, o fotógrafo não se atém apenas ao que está disponível à sua percepção visual, em outros termos, ao que ele enxerga. Antes de tudo, há um processo de reconhecimento e seleção estabelecido a partir de categorias, ancoradas em seu universo social, que o ensinaram a ver (GOMBRICH, 1996).

A tomada desse tipo de consciência encontra espaço no debate sobre fotografia e arte difundido por meio dos manuais de fins do século XIX. No estabelecimento de algumas bases intelectuais que criavam parâmetros para o exercício da atividade discutia-se, nessas publicações, para que servia fotografar e qual sua função na vida cotidiana. Sob essa perspectiva, a fotografia exercida pelo homem comum, que organizava por meio de álbuns a memória familiar, era também interpretada como um meio de educação artística, instrumento de observação e conhecimento do mundo. Deste modo, o desenvolvimento das 
aptidões necessárias para essa pedagogia do olhar teria implicações mais amplas na vida cotidiana. No manual Le photographe portraitiste, de C. Klary, publicado em 1892, L'education artistique de l'oeil, assim é tratada:

L'oeil éduqué voit des tableaux complètement séparés des choses étrangères qui les environnent, il les perçoit ainsi que cela doit être, mentalement, sur une toile imaginaire, admirables et complets en eux-mêmes; ils experiment toujours un événement quelconque, en excitant chez lui une émotion qui le satisfait par une pensée.

Cette faculté de voir des tableaux précède immédiatement le pouvoir de les produire.

[...] Aucune représentation convenable ne peut être obtenue sans une idée préalable, conçue d'une semblable manière ${ }^{14}$ (p. 123).

Na década de 1890, na busca para um estatuto artístico para a fotografia, surge nos países Europeus - França e Inglaterra - e EUA o movimento conhecido por pictorialismo, que teve amplo alcance sobre o campo amador. Esses grupos difundiam o uso de experimentações por meio de materiais que podiam atribuir cores, texturas e formatos diferentes aos suportes, pois tratavam as imagens produzidas tecnicamente tal como a tela de um pintor. Na aplicação direta de modelos extraídos das belas artes à fotografia, o perfeito controle sobre os processos laboratoriais tornava-se imprescindível (MELLO, 1998).

Não procuramos aqui validar o papel do pictorialismo nas fotos de Sampaio, até porque seus recursos e modelos clássicos não são reconhecidos nessa série. $E$, além do mais, os debates a respeito desse movimento, no Brasil, apareceram apenas no final da primeira década do século $X X$, quando foram fundados os "photo-clubs"15. O que pretendemos é apenas compreender algumas conseqüências decorrentes do processo de "formação do olhar" que, ao preconizar o encontro com a maior diversidade de culturas teve como efeito imediato a revalorização da prática da excursão fotográfica.

\footnotetext{
${ }^{14} \mathrm{O}$ olhar educado vê as cenas completamente separadas das coisas que são estranhas ao seu ambiente e que estão à sua volta, ele as percebe como elas devem ser notadas mentalmente sobre uma tela imaginária, admiráveis e completas nelas mesmas; essas cenas expressam sempre um acontecimento qualquer, provocando uma emoção que o satisfaz [o olhar educado] como se fosse um pensamento. Essa capacidade de antever os quadros antecede imediatamente o poder de lhes produzir. Nenhuma representação conveniente pode ser obtida sem uma idéia que a preceda, concebida dessa tal maneira.

${ }^{15} \mathrm{Em} 1910$ foi fundado o Photo-Club do Rio de Janeiro que nos anos 1920 se transformou no Photo Club do Brasil, instituição formada por amadores que se dedicavam à fotografia «artística » (MELLO, 1998).
} 
Compondo esse quadro surgem nos países europeus e EUA sociedades como a (SEAP) Société d'excursions des amateur photographes fundada na França em 1887, por um amador, o médico Albert Londe ${ }^{16}$ (POIVERT, 2001). Alguns manuais passam também a abordar o tema como Traitè des excursions photographiques, de 1889, e L'amateur d'excursions photographiques, de 1895, ambos de autoria de J. F. Hermagis ou La photographie en voyage et en excursion de 1894, de um dos mais populares e lidos autores do período, Gaston-Henri Niewenglowski.

Há que se reconhecer que o exercício da viagem, segundo o modelo das expedições, existiu desde o início da difusão da fotografia, ocupando seu espaço na busca pelo exótico a partir do confronto com culturas antes desconhecidas. Podiam tanto ter o caráter informativo como estarem associadas à expansão colonialista. Os manuais também já contribuíam para a estimulação dessa atividade no período em que o colódio úmido era a técnica corrente. Nos tópicos abordando as excursões ensinava-se, inclusive a fabricar barracas necessárias ao manuseio e preparo de químicas e negativos. Fazer expedições ficava restrito, no entanto, àqueles que dominavam todos os procedimentos para a realização das tomadas (TURAZZI, 1995; FABRIS, 1998).

No final do século XIX, essa situação iria mudar, com as facilidades técnicas colocadas ao alcance de grupos cada vez mais extensos. A isso se adensaram outras práticas que reiteraram a idéia da viagem como meio de conhecimento, dentre as quais temos o colecionismo ilustrado - um exemplo direto são os cartões-postais - as revistas que começam a publicar fotografias e o modelo de excursão propagada nos circuitos amadores.

É nesse contexto que Alberto de Sampaio se defronta com a outra cultura de Copacabana, a dos pescadores. Ao estender seu olhar para além dos artefatos, ele retrata as figuras humanas no desempenho das atividades, como observamos na fotografia da chegada dos peixes na praia - uma cópia em papel editada no formato panorâmico, diferentemente do negativo utilizado (FIGURA 13). Nesta tomada aparece, no primeiro plano, um observador sentado à esquerda em direção aos homens que estão mobilizados, participando de forma

\footnotetext{
${ }^{16}$ Albert Londe, diretor do hospital Salpetrière, foi fotógrafo amador e precursor da fotografia aplicada à medicina. Publicou La photographie médicale. Application aux sciences médicales et physiologiques e também Du rôle de l'amateur de photographie au point de vue artistique et scientifique, ambos em 1893.
} 
direta da ação. O grupo extravasa o campo fotográfico alongando visualmente ainda mais a panorâmica.

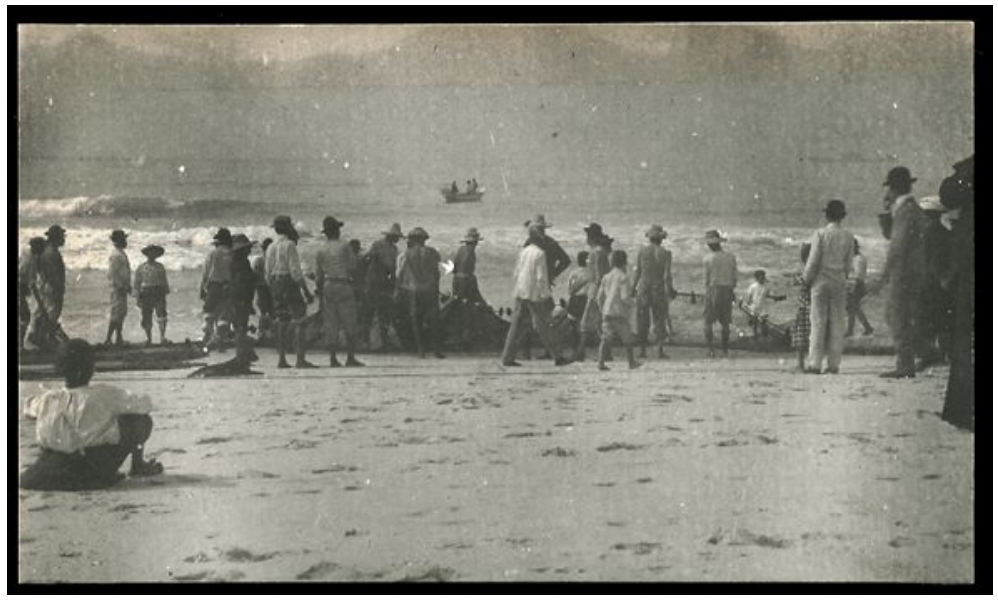

FIGURA 13. Pescadores em Copacabana. Cópia em papel a partir de negativo de celulóide (gelatina/prata), 9,0 x $5,0 \mathrm{~cm}$. Título atribuído.

Data: $1906-1910$

Autor: Alberto de Sampaio.

Acervo Eduardo Soares de Sampaio Filho

Além do exercício da excursão, essa proximidade com o objeto a ser retratado tem na possibilidade técnica da fotografia instantânea um outro aliado - nesse caso, foi utilizado filme e câmera kodak. A empresa que desenvolveu estratégias bem sedimentadas de propaganda explora, igualmente, a idéia da viagem expedicionária, só que agora em termos da cultura do lazer como consumo, delineada em fins do século XIX. Isso ocorria num período em que a antiga noção do "lazer cultivado", expressão utilizada por Alain Cobin, ainda se fazia presente entre aqueles que dispunham do tempo livre e podiam se dedicar como amadores às artes, à ciência, ao colecionismo e, podemos acrescentar, à fotografia (VIDAL, 2005). O foco da empresa, contudo, se direcionava para o modelo de lazer que estava circunscrito à esfera produtiva da sociedade, cujas implicações podem ser notadas no desenvolvimento do turismo de massa. Em uma de suas propagandas, a Kodak assim se dirige aos amadores: "Travellers and tourists: Use it to obtain a picturesque diary of their travells... Bicyclists and 
boating men: Can carry it where a larger câmera would be too burdensome.......] 17" (apud WELLS, 2004: 142, grifo original).

A convergência entre esses dois parâmetros encontrava meio de propagação em outras atividades, como o ciclismo citado na propaganda da Kodak. Não é por um acaso que Alberto de Sampaio foi fundador do Cicle Club do Brasil, entidade sediada em Petrópolis que organizava passeios ciclísticos entre as cidades do Rio de Janeiro e Juiz de Fora. Segundo o texto do próprio Sampaio, publicado no Almanak Ciclístico de 1899, esse era o primeiro clube que se ocupava do "tourismo em bicyclette" (p. 83, grifo original).

O olhar mediado por essas transformações reconhece e interage através de categorias que se adensam aos antigos processos de construção da paisagem. Para o fotógrafo amador que se encontra na convergência desses diversos vetores é possível adentrar no ambiente seja como meio de consumo ou de fruição do cenário. Na última imagem da série, Sampaio se mistura à atividade do pescador descarregando peixes (FIGURA 14). Há uma moldura na imagem formada também por observadores - no caso crianças, certamente habitantes do local. A posição do pescador, com o braço estendido em diagonal, valoriza o instantâneo do momento em que o peixe está sendo lançado no chão.

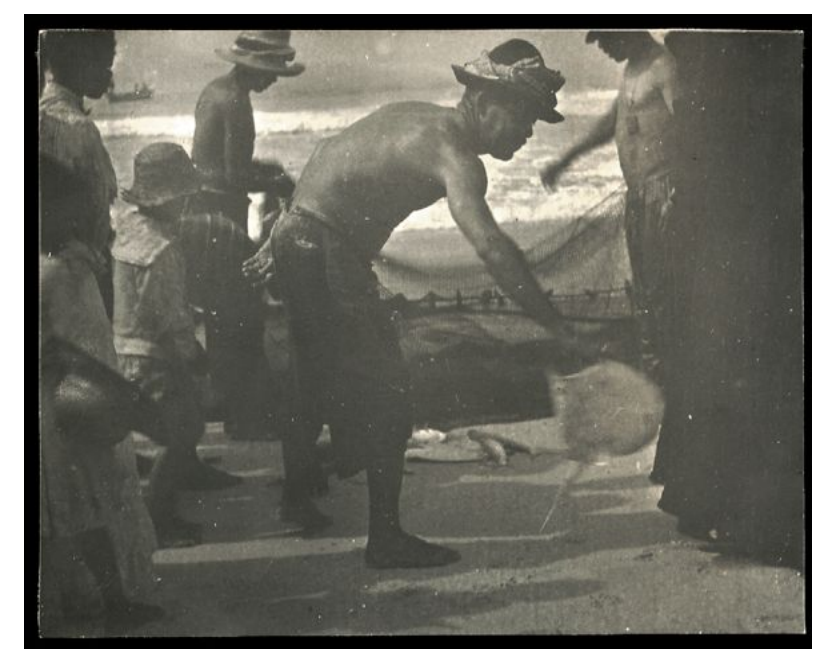

FIGURA 14. Pescador com arraia em Copacabana. Cópia em papel a partir de negativo de celulóide (gelatina/prata), $8,5 \times 7,0 \mathrm{~cm}$. Título atribuído.

Data: $1906-1910$

Autor: Alberto de Sampaio. - Acervo Eduardo Soares de Sampaio Filho.

\footnotetext{
17 Viajantes e turistas : Use-a [kodak] para obter um diário pitoresco de suas viagens... Ciclistas e navegadores : Podem levá-la no lugar da camera de grandes dimensões que pode ser muito difícil de se carregar...[...].
} 
No processo de seleção daquilo que parece condensado ao olhar do fotógrafo, dentro de todas as possibilidades existentes na região, o homem deixa de ser integrante, tornando-se ele mesmo num agente da paisagem. No manual La pratique en photographie de Frederic Dillaye, de 1900, no capítulo sobre Le paysage o autor reflete sobre o desenvolvimento desse modelo de interpretação da natureza:

La peinture, a-t-on dit pendant longtemps, consiste l'imitation de la nature. Définition mauvaise confondent le moyen avec le but.

La nature, en effet, n'ést pas seulement um modèle à imiter, mais um thème à interpréter. Le jour où cette science du sentiment que l'on nomme esthétique se dégagea du cervau humain, on comprit qu'un art graphique présentait autre chose qu'une simple imitation. Devant cette question: qu' est-ce que l'art? On dut répondre avec Bacon: c'est l'homme s'ajoutant à la nature, homo additus naturae. ${ }^{18}$ (p. 40, grifo original).

Esse olhar educado pela literatura especializada, a ressignificação das práticas de viagem como forma de conhecimento e as facilidades técnicas surgidas no campo da fotografia amadora, dentro do novo contexto em que se apresentavam as categorias de lazer e turismo, promoveram mudanças em relação à apreensão do que era considerado como "visível". Num momento em que as discussões desencadeadas pelas reformas urbanas são colocadas em evidência em torno do "Rio civiliza-se", o passado colonial era validado como símbolo do atraso (NEEDELL: 1993). As fotografias tornam-se, do mesmo modo, parte integrante daquilo que era considerado a memória nacional, vinculando-se ao discurso modernizador que legitimava os "melhoramentos". No entanto, o olhar que se mantinha sempre atualizado, dentro desse campo amador, reorganizava o que era "visto", apontando diferentes proposições.

Obviamente, não identificamos nessa manifestação a existência de uma visão crítica sobre a mesma sociedade, nem muito menos, no nosso caso de estudo, Sampaio está à procura de algum fator constituinte de uma característica nacional. $\mathrm{O}$ interessante desse processo é perceber como em suas fotografias,

\footnotetext{
${ }^{18}$ A pintura foi interpretada durante muito tempo atrás como a imitação da natureza. Definição errada que confunde o meio com o objetivo. A natureza de fato não é somente um modelo à imitar, mas um tema a interpretar. O dia em que esta ciência do sentimento que nós nomeamos de estética se libertara do cérebro humano, compreendemos que uma arte gráfica apresentava outra coisa que uma simples imitação. Perante esta questão: o que é arte ? Repondemos como Bacon : é o homem se juntando à natureza, homo additus naturae.
} 
elaboradas dentro do campo de possibilidades estabelecidas para esse olhar educado, surge a documentação de algo que não estava sendo o foco das atenções dos segmentos sociais mais privilegiados. $O$ fato é que os pescadores só "aparecem" em outra fase da história da fotografia brasileira.

É instigante pensar que a pesca era uma atividade economicamente importante para o bairro, mas mesmo assim a representação direta desses trabalhadores demoraria a penetrar nas manifestações visuais da sociedade do período. Já em torno de 1850, o empresário Carlos Leblon, dono da antiga fazenda Copacabana, tinha uma empresa de pesca de baleias chamada "Aliança". No final do século XIX houve, durante alguns anos, um "bonde peixeiro" reboque atrelado ao bonde da Companhia Jardim Botânico que levava o carregamento ao centro da cidade. Em 1899, consta que o conselho municipal tenta proibir a circulação desse transporte, possivelmente por incomodar os ainda poucos moradores do bairro (DUNLOP, 1973).

Consideramos, portanto, a partir dos pontos apresentados, que esse fotógrafo amador, como um receptor e produtor de imagens ressignifica a noção de viagem em meio às transformações que ocorriam naquela sociedade. Por meio da experiência da excursão, estabelecida sob os moldes do consumo de fins de século XIX, ele vai de encontro ao nascimento da indústria do turismo. Nesse processo, situado no ponto de convergência de diversas influências, esse amador estabelece uma outra "faculdade de ver", se antecipando aos profissionais na formulação de novos repertórios. 


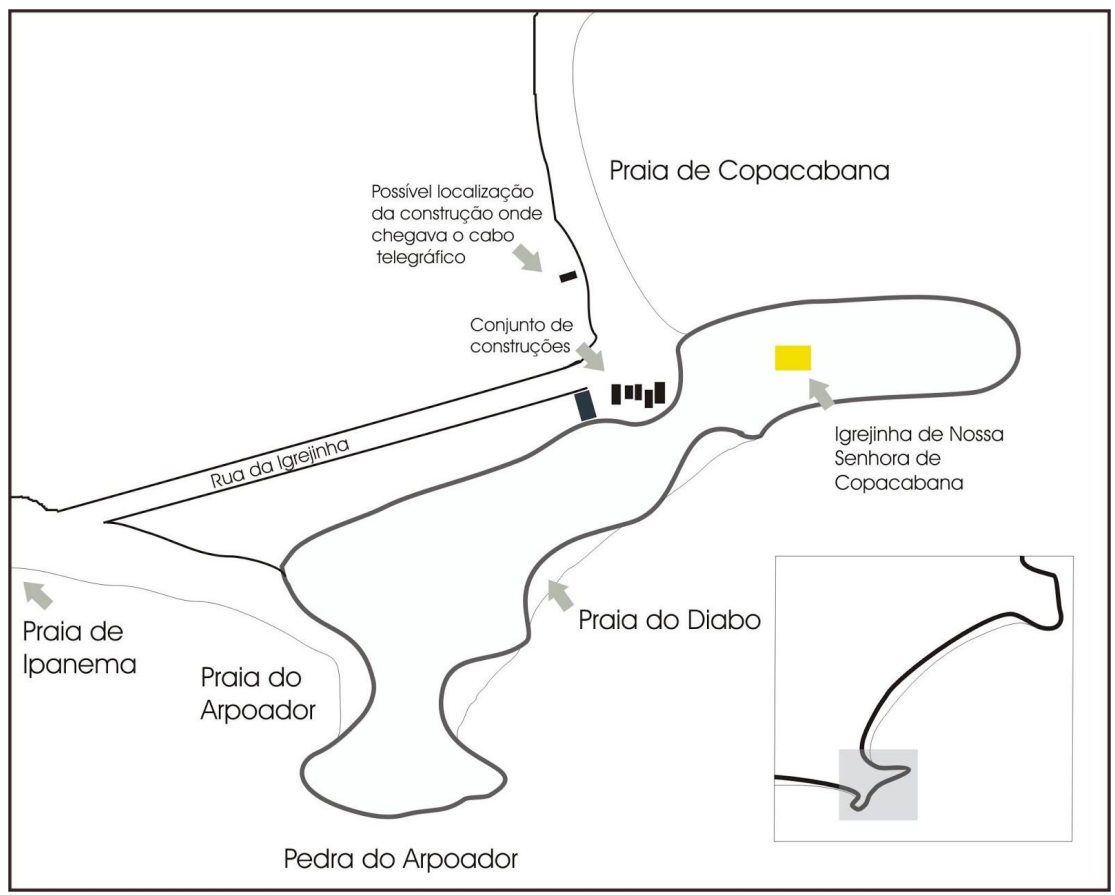

FIGURA 15. Mapa entre Copacabana e Ipanema. A rua da Igrejinha é a atual Francisco Otaviano. Segundo Dunlop (1973) a construção que abrigava o cabo telegráfico ficava situada no trecho assinalado no mapa.

\section{Referências bibliográficas:}

Almanak cyclistico e annuario do cycle club do Brasil (1899). Petrópolis.

ABREU, Maurício de Almeida (1988). A Evolução Urbana do Rio de Janeiro, $2^{\text {a }}$ ed. Rio de Janeiro: Iplanrio/Zahar.

BERGER, Paulo e Eneida (1959). História dos bairros: Copacabana. Rio de Janeiro: departamento de história do distrito federal.

BELLUZZO, Ana Maria de Moraes (1999). O Brasil dos Viajantes, Vol. III: A construção da paisagem, $2^{a}$ edição. São Paulo: Metalivros; Rio de Janeiro: Editora Objetiva.

CARDOSO, Elisabeth et al. (1986). História dos bairros: Copacabana. Rio de Janeiro: João Fortes Engenharia/Index Editora.

CARVALHAL, Alberto Pereira (1908). Manual do photographo ou guia pratico do amador photographico. Lisboa : Ed. Arnaldo Bordalo. 
CARVALHO, Vânia Carneiro de (1998). As representações da natureza na pintura e na fotografia brasileiras do século XIX. In: FABRIS, Annateresa (Org.). Fotografia: usos e funções no século XIX, $2^{a}$ ed. São Paulo: Edusp.

VIDAL, Laurent (2005). Alain Corbin o prazer do historiador. Revista Brasileira de História, São Paulo, v. 25, n. 49, p. 11-41.

CRULS, Gastão (1949). Aparência do Rio de Janeiro. Notícia histórica e descritiva da cidade, Vol. 2. Rio de Janeiro: Livraria José Olímpio Editora.

DEBRET, Jean Baptiste (1940). Viagem pitoresca e histórica ao Brasil, 1816-1831, Tomo II, Vol. III. São Paulo: Livraria Martins.

DILLAYE, Frederic (1900). La pratique en photographie avec le procédé au gélatino-bromure d'argent. Paris: Librairie illustrée.

DUNLOP, Charles Julius (1973). Chronicas - Fatos, gente e coisas da nossa história. Rio de Janeiro: CEA.

DUNLOP, Charles Julius. (1953). Apontamentos para a História dos Bondes no Rio de Janeiro, Vol. 2: a Companhia Ferro Carril do Jardim Botânico. Rio de Janeiro: Editora Gráfica Laemmert, 1953.

EDMUNDO, Luis (1957). O Rio de Janeiro de meu tempo, Vol. 4. Rio de Janeiro: Conquista.

FABRIS, Annateresa (org.) (1998). Fotografia: usos e funçoes no século XIX, $2^{a}$ edição. São Paulo: Edusp.

FERREZ, Gilberto (1984). O Rio antigo do fotógrafo Marc Ferrez: 1865-1918. São Paulo: João Fortes Engenharia/ Ex Libris.

GRANGER, A (1895). Guide du photographe amateur. Paris: Rueff et cie. Éditeurs.

GERSON, Brasil (2000). História das ruas do Rio: e da sua liderança na história política do Brasil, $5^{\text {a }}$ edição. Rio de Janeiro: Lacerda Editores.

GOMBRICH, Ernest (1995). Arte e ilusão: um estudo da psicologia da representação pictórica. São Paulo: Martins Fontes.

HERMAGIS, J. F (1889). Traitè des excursions photographiques. Paris: Rongier \& Cie.

HERMAGIS, J. F (1895). L'amateur d'excursions photographiques. Publication trimestrielle et illustrée complémentaire du "Traité des excursions ". Paris: Chez l'auteur. 
KLARY, C. (1892). Le photographe portraitiste. Paris: Societé d'Editions Scientifiques.

LUCCOCK, John (1951). Notas sobre o Rio de Janeiro e partes meridionais do Brasil tomadas durante uma estada de dez anos nesse país, de 1808 a 1818, $2^{\text {a }}$ edição. São Paulo: Livraria Martins Editora.

MAUAD, Ana Maria (2000). A inscrição na cidade: paisagem urbana nas fotografias de Marc Ferrez e Augusto Malta. In: SALGUEIRO, Heliana A. (org). Paisagem e Arte, São Paulo: CNPq, FAPESP, CBHA.

MELLO, Maria Teresa Bandeira de (1998). Arte e fotografia: o movimento pictorialista no Brasil. Rio de Janeiro: Funarte.

MENESES, Ulpiano Toledo Bezerra de (2002). A paisagem como fato cultural. In: YÁZIGI, Eduardo (org.). Turismo e paisagem. São Paulo: Contexto, p. 29-64.

NEEDELL, Jeffrey D (1993). Belle Èpoque tropical: sociedade e cultura de elite no Rio de Janeiro na virada do século. São Paulo: Companhia das Letras.

NIEWENGLOWSKI, Gaston-Henri (1894). La photographie en voyage et en excursion. Paris : Société d'éditions scientifiques.

PEREIRA, Sônia Gomes (1992). A reforma urbana de Pereira Passos e a construção da identidade carioca. Tese de doutorado em Comunicação e Cultura, Rio de Janeiro, ECO-UFRJ.

PEREIRA, Adriana Maria Martins (2004). Lentes da memória: a fotografia amadora e o Rio de Janeiro de Alberto de Sampaio (1888-1930). Dissertação de mestrado do programa de pós-graduação em Memória Social da Universidade Federal do Estado do Rio de Janeiro, UNIRIO.

POIVERT, Michel (2001). La Photographie Française em 1900. L'échec du pictorialisme. Vingtième Siècle. Revue d'histoire, 72, octobre-decembre, p.17-25. SANTOS, Noronha (1996). Meios de transporte no Rio de Janeiro: história e legislação, Vol. 1, $2^{a}$ edição. Rio de Janeiro: Secretaria Municipal de Cultura.

TURAZZI, Maria Inês (2002). Marc Ferrez: fotografias de um "artista ilustrado". São Paulo: Cosac \& Naif Edições.

TURAZZI, Maria Inês. (1995). Poses e trejetos: a fotografia e as exposições na era do espetáculo, 1839-1889. Rio de Janeiro: Rocco.

VASQUEZ, Pedro (2002). Postais do Brasil, 1893-1930. São Paulo: Metalivros.

VILLAÇA, Flávio (1998). Espaço intra-urbano no Brasil. São Paulo: Studio Nobel/FAPESP/Lincoln Institute. 
WELLS, Liz (ed.) (1998). Photography: a critical introdution. London and New York: Routledge.

Texto recebido em: 01/10/2007. 